\title{
SCRUTINIZING THE ROLE OF ARABIC IN SHAPING LITERACY IN INDONESIA
}

\author{
Pradi Khusufi Syamsu \\ IAIN Syekh Nurjati Cirebon, Indonesia \\ Email: pradikhusufi@gmail.com
}

\begin{abstract}
This article concludes that Arabic has a very significant role in shaping the culture of literacy in Indonesia. Arabic influences Indonesian from script to semantic, lexicographic, and grammatical. Islam is synonymous with the Arabic language able to change the views of Indonesian people who originally orientedart only with beautiful temples into a book-oriented manifestation with the creation of many writings in the form of manuscripts that were born thousands and even millions of manuscripts.

This study is a literature study. The author uses two approaches in social sciences that are, historically, to know social, cultural and political phenomena; while the philology approach is used to find out Arabic Jawi manuscripts that are actually rich in unexpected information.
\end{abstract}

Keywords: Arabic, Literacy, Manuscripts, Indonesia, Malay

\section{Introduction}

Almost all civilizations on the earth that come into contact with Islam must be arabize. When Islam came into contact with the Persian civilization it was born calligraphy fârisî, when Islam "set foot" in Bashrah was born calligraphy kûfî. Similarly, with other civilizations such as Syria, Egypt, ${ }^{1} \mathrm{China}^{2}$ and can not be denied also with civilization in the archipelago with a lot of Arabic vocabulary that entered into the Indonesian language and the Arabic script Jawi or Jawi in Malay language and Arabic script Pegon using Java language and Sunda with Arabic.

${ }^{1}$ Shah Muhammad Shafiqullah, Calligraphic Ornamentation in The Architecture of The Umayyad of Syria: A Brief Survey, on The Islamic Quarterly: A Review of Islamic Culture. (London: Volume XXXVII, 1993). p. 224. In fact, Annemarie Schimmel writes in her book that the names of Muslims are synonymous with Arabic. See Annemarie Schimmel, Islamic Names. (Edinburgh: Edinburgh University Press, 1995). p. 1-79.

${ }^{2}$ Lihat Dru C. Gladney, Seeking Knowledge unto China: Traditionalization, Modernity and The State, onJohan Meuleman (ed), Islam in The Era of Globalization: Muslim Attitudes Towards Modernity and Identity. (Jakarta: INIS, 2001). p. 266-277. 
Malay, as the forerunner of the Indonesian language, is the most widely accepted language of Arabic influence, especially in terminology and script. ${ }^{3}$ Azyumardi Azra noted that Al-Hamidi's dictionary lists about 2,000 Arabic vocabularies, the Arabian Jawi Dictionary dictionary records 1725 Arabic vocabularies, less than 2,000 Arabic vocabularies, the dictionary of the Tengku Iskandar compound of 1,100 vocabularies, and the national dictionary, by Mohd. Kadir, registering 1,125 words. Meanwhile, Sudarno recorded 2,302 Arabic words in Indonesian. As for non-Malay researchers such as James Howison records only 150 Arabic vocabularies, Shellabear, who compiled a Malay-English dictionary, listed as many as 385 words, Winstedt and Linggi in Malay loghat recorded 1,001 Arabic vocabularies. Further, in the Wilkinson dictionary, An Abridge MalayEnglish Dictionary records 892 Malay loan words from Arabic. ${ }^{4}$

\section{Method}

This study is a literature study. The author uses two approaches in the social sciences $^{5}$ that is, historically ${ }^{6}$ to know social, cultural and political phenomena; while the philology approach ${ }^{7}$ is used to find out Arabic Jawi manuscripts that are actually rich in unexpected information. ${ }^{8}$ The method to be used is a deductive method and inductive method. ${ }^{9}$ The two methods will be used in empirical data collection, according to the object. However, to find a general principle ${ }^{10}$ in this study the data are put together and read together (induced). On the contrary, the general principle or conclusion clarifies a lot of data that is not very clear meaning,

${ }^{3}$ Azyumardi Azra, Renaisans Islam Asia Tenggara; Sejarah Wacana dan Kekuasaan. (Bandung: PT Remaja Rosdakarya, 2006). p.76.

4 Azyumardi Azra, Renaisans Islam Asia Tenggara; Sejarah Wacana dan Kekuasaan. (Bandung: PT Remaja Rosdakarya, 2006). p.76-77.

${ }^{5}$ Henry Pratt Fairchild (ed), Dictionary of Sosiology and Related Sciences. (New York: Littlefield, Adam \& Co. Ottowa). p. 292. Juhaya S Praja, Filsafat dan Metodologi Ilmu dalam Islam dan Penerapannya di Indonesia. (Bandung: Teraju, 2002). p. 47-48.

${ }^{6}$ Uka Tjadrasasmita, Kajian Naskah-Naskah Klasik dan Penerapannya bagi Kajian Sejarah Islam di Indonesia. (Jakarta: Puslitbang Lektur Keagamaan Depag, 2006). p. 6.

7 Nabilah Lubis, Pentingnya Pendekatan Filologi dalam Studi Keislaman. (Jakarta: IAIN Syarif Hidayatullah, 1998). p. 1-17.

${ }^{8}$ Uka Tjandrasasmita, An Explanation of the Study of Philology and its Application to the Study of Islamic History in Indonesia. on Jurnal Lektur Keagamaan, vol. 4, No. 1, 2006. p. 78.

${ }^{9}$ In every science there is the use of induction and deduction methods according to what is called the empirical cycle.Seet R.F. Beerling, S.L. Kwee, J.J.A. Mooij and C.A van Peursen, Pengantar Filsafat Ilmu. (Yogyakarta: Tiara Wacana, 1986). p. 54.

${ }^{10}$ Paul Ricoeur, Hermeunetics and the Human Sciences; Essays on Language, Action and Interpretationtranslated by J.B. Thompson. (Cambridge: Cambridge University Press, 1982). p. 14-15. 
when viewed loose (deduction). In this process, the researcher will accept the reality as it is as objectively as possible but by simultaneously engaging in the concepts he investigates. ${ }^{11}$

\section{The Rise of TheWriting Tradition}

The presence of Islam in the Malay-Indonesian archipelago is a very important moment in history to the development of this archipelago, its presence in the archipelago is almost similar to the arrival of Islam in Europe in the Middle Ages which had a major influence on changing the worldview of Europeans to deliver it to the century of enlightenment. ${ }^{12}$ The influence of Islam on this archipelago has never been achieved by any religion, including Hinduism and Buddhism that first came into contact with these islands. Although Majapahit as a representation of political power Hinduism and its religion and culture, and Sriwijaya as representatives of Buddhist political, religious and cultural forces, there is no significant contribution in the renaissance of the Malay-Indonesian archipelago.

The most fundamental proof is the success of Malay in the archipelago, where language is not only a means of communication but also in it radiates the way the power of reason and reason encapsulates the thinking of a nation. In fact, Jurgen Habermas as quoted by Majid Tehranian states that a language is a tool of domination and strength, ${ }^{13}$ further Jean Baudrillard said that the word is a real monopoly. ${ }^{14}$ Later, Azyumardi Azra asserted that the unity of language and terminology is the key to peace. ${ }^{15}$

The arrival of Islam in the archipelago made the Malay language evolved into the language of books, literature, and culture. The upgrading and development of Malay were first conceived by scholars and scholars of the

11 Anton Bakker and Achmad Charris Zubair, Metodologi Penelitian Filsafat. (Yogyakarta: Kanisius, 1998). p. 94-95.

12 Syed Naquib al Attas, Preliminary Statement on a General Theory of the Islamization of the Malay-Indonesian Archipelago. (Kuala Lumpur: Dewan Bahasa dan Pustaka, 1969). p. 2 dan 7.

${ }^{13}$ Majid Tehranian, Technologies of Power: Information Machines and Democratic Prospects. (New York: Ablex Publishing Company, 1990). Hal. 39.

${ }^{14}$ Jean Baudrillard, For a Critique of the Political Economy of the Sign, translated by C. Levin. (St. Louis: Telos Press, 1981). p. 182.

${ }^{15}$ Azyumardi Azra, Esei-esei Intelektual Muslim dan Pendidikan Islam. (Ciputat: Logos, 1999). p. 137. 
Sultanate of Aceh. In the writing dimension, they adapted the Arabic script ${ }^{16}$ in accordance with the Malay tongue, then the script was known as the Malay Arabic script or Jawi, in accordance with the customs of the Holy Land community which referred to the whole of Southeast Asia as "jawah" and the inhabitants called "Jawi". ${ }^{17}$

Braginsky compares Javanese culture to Malay. Javanese culture in Hinduism and Buddhism views the universe as a work of art manifested by beautiful temples. In contrast to Malay culture after contact with Islam view nature as a book that embodied the creation of many writings in the form of manuscripts. ${ }^{18}$ Taufik Abdullah added, that after Java in touch with Islam, not a few manuscripts in the Java language using Arabic script stored in the museum Sonobudoyo Yogyakarta. ${ }^{19}$ The local archipelagic languages are also inevitable as yellow book definitions proposed by Azyumardi Azra include all religious books that speak Arabic as well as local languages in the archipelago while still using Arabic script in their writing. ${ }^{20}$ So not only Malay, even all civilizations that come into contact with Islam is almost inevitable for its clarity.

The value of art that is manifested in the writing world in Jawi script is not inferior to the elegance of Hindu-Buddhist temples. Mu'jizah recorded at least 552 illuminated letters full of meaning and historical value during the Dutch colonial period. ${ }^{21}$ Arabic script after the decline of the Qur'an also experienced a very rapid development and is one-one letters rich in the model and full of art value..22 Even the writing of Arabic letters in Malay is not only to broadcast the religion of Islam but also to grow the nationalist attitude that releases the nations in the archipelago from the shackles of Portuguese, Dutch and Japanese colonizers. ${ }^{23}$

${ }^{16}$ Azyumardi Azra, Esei-esei Intelektual Muslim dan Pendidikan Islam. (Ciputat: Logos, 1999). p. 138.

${ }^{17}$ Nurcholish Madjid, Indonesia Kita. (Jakarta: Universitas Paramadina, 2004). p. 37-38.

18 Vladimir Braginsky, The Herritage of Tradinional Malay Literature; A Historical Survey of Genres, Writings and Literary Views. (Leiden: KILTV Press, 2004). p. 1.

${ }^{19}$ Taufik Abdullah, Pengantar. on Azyumardi Azra, Renaisans Islam Asia Tenggara; Sejarah Wacana dan Kekuasaan. (Bandung: Rosdakarya, 2006). p. ix-x.

${ }^{20}$ Azyumardi Azra, Pendidikan Islam; Tradisi dan Modernitas Menuju Milenium Baru. (Ciputat: Logos, 1999). p. 111.

${ }^{21}$ See Mu'jizah, Iluminasi dalam Surat-surat Melayu Abd ke-18 dan ke-19. (Jakarta: KITLV dan Pusat Bahasa-Depatemen Pendidikan Nasional, 2009).

${ }^{22}$ See Sirodjuddin AR, Seni Kaligrafi Islam. (Jakarta: Pustaka Panjimas, 1985).

${ }^{23}$ Mat Akhir Haji Sanawi Muhammad, Kitabah al Lughah al Malaziyah bi al Huruf al 'Arabiyyah. (Khurthum: Risalah Diplom Ma'had Khurthum ad Dauly, 1403/1983). p. 11. 
Selection of Malay as the language of instruction in the process of broadcasting Islam in the archipelago certainly not without reason. When compared, the Old Malay language is not much different from the pre-Islamic Arabic, both do not take the role of an aesthetic religion language. Such a single role in the archipelago is taken from Ancient Java and Sanskrit, as in the Middle East and its neighbors played by Ancient Greco-Roman and Ancient IranianPersian. Thus, the selection of Malay as the main language in broadcasting Islam which was then Islamized certainly not a coincidence and without the basis of knowledge and experience. They, the broadcasters of Islam, have made the experience of Arabic as a reference in choosing the language for Islamic broadcasting that falls on the Malay language. Despite their deep knowledge of the archipelago because of the contact between pre-Islamic Arabs has occurred in these islands, from the Jahiliyyah period. ${ }^{24}$

\section{The Influence of Arabic in Bahasa Indonesia}

Malay, as the forerunner of the Indonesian language, is the most widely accepted language of Arabic influence, especially in terminology and script. ${ }^{25}$ Azyumardi Azra noted that Al Hamidi's dictionary lists about 2,000 Arabic vocabularies, the Malay Arabian Dictionary dictionary records 1725 Arabic vocabularies, less than 2000 Arabic vocabulary dictionaries, Tengku Iskandar's dictionary council records 1,100 vocabularies, and the national dictionary, Mohd's. Kadir, registering 1,125 words. Meanwhile, Sudarno recorded 2,302 Arabic words in Indonesian. As for non-Malay researchers such as James Howison records only 150 Arabic vocabularies, Shellabear, who compiled a Malay-English dictionary, listed as many as 385 words, Winstedt and Linggi in Malay Loghat recorded 1,001 Arabic vocabularies. Further, in the Wilkinson dictionary, An Abridge MalayEnglish Dictionary records 892 Malay loan words from Arabic. ${ }^{26}$

${ }^{24}$ Syed Naquib al Attas, Preliminary Statement on a General Theory of the Islamization of the Malay-Indonesian Archipelago. (Kuala Lumpur: Dewan Bahasa dan Pustaka, 1969). p. 27-29. See T.W. Arnold, The Preaching of Islam; A History of Propagation of the Muslim Faith. (New Delhi: Aryan Books International, 2002). p. 363-407.

${ }^{25}$ Azyumardi Azra, Renaisans Islam Asia Tenggara; Sejarah Wacana dan Kekuasaan. (Bandung: PT Remaja Rosdakarya, 2006). p.76.

${ }^{26}$ Azyumardi Azra, Renaisans Islam Asia Tenggara; Sejarah Wacana dan Kekuasaan. (Bandung: PT Remaja Rosdakarya, 2006). p.76-77. 
The large number of Arabic vocabularies adopted and adapted in Malay, rather than other languages, ${ }^{27}$ is closely related to the Islamization process in the archipelago since Islamization is indeed synonymous with Arabization, not Arabism. ${ }^{28}$ With the broadcasting of Islam, the spread of Arabic elements slowly but surely infecting the archipelago. The intensive and significant influence of Arabic into the Malay language dates back to the 14th century, and the process still continues to this day in the Malay-Indonesian archipelago..$^{29}$ Consistently lending Arabic words originates from classical Arabic literature and from standard Arabic language in the contemporary era. Regional languages are not sterile from borrowing Arabic words, albeit in relatively small amounts. However, the exact cause is that Islam has brought Arabic and its literature spread from hand to hand across the archipelago. ${ }^{30}$

The influence of Islam in the use of the Malay script is also inevitable, the adoption and adaptation proceeded simultaneously until gradually created five characters that did not exist in Arabic sound, but still refers to the form and sound of Arabic script. The six characters are:

\begin{tabular}{|c|c|c|}
\hline o & $\begin{array}{c}\text { Additional } \\
\text { Script }\end{array}$ & Sound \\
\hline & $\varepsilon$ & $\mathrm{Ca}$ \\
\hline & $\dot{\varepsilon}$ & $\mathrm{Nga}$ \\
\hline & $\dot{\mathrm{s}}$ & $\mathrm{Pa}$ \\
\hline & $\dot{\zeta}$ & $\mathrm{Ga}$ \\
\hline & $\dot{u}$ & $\mathrm{Nya}$ \\
\hline & $\dot{9}$ & $\mathrm{~V}$ \\
\hline
\end{tabular}

The formation of the letters ca (ङ), as found in the Arabic-Persian script, is a combination of the taand jim characters, hence the three-pointed jim; the $n g a(\dot{\xi})$

${ }^{27}$ Antonio Pinto da Franca, Pengaruh Potugis di Indonesia, translated by Katoppo. (Jakarta: PT. Penebar Swadaya, 2000). See Russell Jones (ed), Loan-Words in Indonesia and Malay. (Jakarta: KITLV dan Yayasan Obor Indonesia, 2008).

${ }^{28}$ D. Sirojuddin AR, Potret dan Pengembangan Seni Kaligrafilslam di Indonesia, on LPTQ Tingkat Nasional, 25 Tahun Musabaqah Tilawatil Qur'an. (Jakarta: LPTQ, 1994). Ensiklopedi Tematis Dunia Islam. (Jakarta: Ichtiar Baru van Hopeve, 2002). p. 293-303.

29 Russell Jones, Introduction, on Russell Jones (ed), Loan-Words in Indonesia and Malay. (Jakarta: KITLV dan Yayasan Obor Indonesia, 2008). Hal. xxiii. See Shamsul Jamili Yeob, The Influence Arabic Language on Modern Malay Arabic Metaphor in Malay Words. (Leeds: Thesis in Arabic Studies at University of Leeds, 1996).

30 Russell Jones ,Introduction, on Russell Jones (ed), Loan-Words in Indonesia and Malay. (Jakarta: KITLV dan Yayasan Obor Indonesia, 2008). p. xxiv. 
script is formed from the nun, ghain and ga characters, two points from nun and ga added to the ghain script to 'ain dotted three; the fa character (ث) is formed from the $b a$ 'allusion with $f a$ ', then added one more point to distinguish it from the qaf (ق) script; $g a$ (3) script is formed because of the sound between two sounds of kaf and jim characters, hence it is formed from the kaf script with the addition of a point from the jim; and its alphabet ( $)$ is a combination of the nun and ya 'characters, which then two points yes' added above $n u n{ }^{31}$ and $\mathrm{v}(\dot{j})$ is a blend of wawu script with the addition of one point of the $f a^{\prime}$ script. ${ }^{32}$ With the addition of six letters corresponding to the Malay-Indonesian dialect, the number of scriptsJawi used for the Malay language is 36 scripts. $^{33}$

Thus, the Islamization ${ }^{34}$ of Malay is not only on the level of semantics, lexicography or grammatical but also its acts. The formation of Malay Arabic script cannot be separated from the form of Arabic script. If no Malay dialect is encountered in Arabic script, then the formation of the script still considers the synthesis of Arabic sounds.

\section{Arabic Encourages Literacy Tradition}

Literacy in Latin is referred to as literatus which means that people are learning. In terms of literacy is the ability of a person to read, write, speak, calculate and solve problems at the level of expertise required in work, family, and society. Merriam Webster's dictionary also explains literacy is the ability or quality of literacy in which there is the ability to read, write and also recognize and understand the ideas visually.

Hamzah Fansuri, Shams ad-Din as-Sumatrani, Ar-Raniri, As-Sinkili, Muhammad Yusuf al-Maqassari, Nawawi al-Bantani, Al-Palimbani, Arsyad alBanjari and Dawud al-Fattani were considered as the lucrative tradition traders in the archipelago.

31 Syed Naquib al Attas, Preliminary Statement on a General Theory of the Islamization of the Malay-Indonesian Archipelago.(Kuala Lumpur: Dewan Bahasa dan Pustaka, 1969). p. 19-21. Compare with D. Gerth van Wijk, Tata Bahasa Melayu. (Jakarta: Djambatan, 1985). p. 11-13. and J.J. de Hollander, Pedoman Bahasa dan Sastra Melayu. (Jakarta: Balai Pustaka, 1984). p. 4.

${ }^{32}$ For one additional script, the point wawu (g) for the V character. See Oman Fathurrahman, Dunia di Balik Tulisan Jawi: Aktualisasi Budaya Melayu dan Islam, on Al Turats, vol. 7, no. 11, Januari 2001. p. 51.

${ }^{33}$ Compare withMat Akhir Haji Sanawi Muhammad, Kitabah al Lughah al Malaziyah bi al Huruf al 'Arabiyyah. (Khurthum: Risalah Diplom Ma'had Khurthum ad Dauly, 1403/1983). p. 35-42.

${ }^{34}$ Syed Naquib Al Attas, Islam and Secularism. (Kuala Lumpur: ISTAC, 1993). p. 44-45. See Alparslan Acikgenc, Islamic Science; towards a Definition. (Kuala Lumpur: ISTAC, 1996). p. 1-31. 
Hamzah Fansuri is a Malay-Indonesian Ulama who lived on before and during the reign of Sultan 'Ala al-Din Ri'ayat Shah who ruled in 997 H / 1589 AD to 1011 H / 1602 AD. he was born in Siam between Singkil and Sibolga. ${ }^{35}$ In addition to Hamzah Fansuri, Syams al-Din al-Sumatrani is also a prominent and prominent Malay-Indonesian cleric of his contemporaries. They both have close relationships and their relationship is believed to be a teacher-student relationship. Hamzah Fansuri is a teacher from Syams al-Din al-Sumatrani.

Hamzah Fansuri is a productive scholar in producing papers. It is supported by the mastery of Hamzah Fansuri against various languages, namely Arabic, Persian and Urdu and his long journey to the Middle East and his visit to the centers of Islamic civilization, such as Makkah, Medina, Jerusalem, and Baghdad. Thus, he was recognized as the Father of Modern Malay Literature where he was the first to use Malay in a rational and systematic manner so that all Malay writers, ulamas and thinkers were subsequently strongly influenced by their styles and methods in the use of Malay language from the 16th century through the 17th and 18th centuries until the 20th century ${ }^{36}$ Even A. Teeuw added that Hamzah the beginner of Indonesian poetry, not just Malay. ${ }^{37}$ Some of them are Shams al-Din al-Sumatrani, Al-Raniri, 'Abd al Ra'uf as Sinkili, Fakhruddin and Amir Hamzah.

Among the works of Hamzah al Fansuri which can be saved from the burning by the royal apparatus on the initiative of Ar Raniri ${ }^{38}$ and which can still be encountered, among others: Asrâr al 'Ârifîn, Syarab al-'Asyiqîn, Al-Muhtadî and Rubâ'i Hamzah al-Fansuri. All three are academic works or referred to as literary works of the book. Sya'ir Jâwi fi Bayân 'Ilm al-Sulûk wa at Tawhîd, Poet of Pingai Bird, Syair Dagang, Syair Jâwi and Sya'ir Perahu ${ }^{39}$ is his writings in poetry or literary form.

35 Abdollah Vakily, Sufism, Power Politics, and Reform; Al Raniri's Opposition to Hamzah al Fansuri's Teaching Reconsidered. on Studia Islamika, vol. 4, no. 1, 1997. p. 119.

${ }^{36}$ Syed Muhammad Naquib al Attas, Islam Dalam Sejarah Dan Kebudayaan Melayu. (Bandung: Mizan, 1984). p. 68.

${ }^{37}$ A. Teeuw, Indonesia Antara Kelisanan dan Keberaksaraan. (Jakarta: Pustaka Jaya, 1994). p. 58.

38 Abdollah Vakily, Sufism, Power Politics, and Reform; Al Raniri's Opposition to Hamzah al Fansuri's Teaching Reconsidered. on Studia Islamika, vol. 4, no. 1, 1997. p. 119-126.

${ }^{39}$ Syed Muhammad Naquib al Attas, Islam Dalam Sejarah Dan Kebudayaan Melayu. (Bandung: Mizan, 1984). Hal. 99-100. See Sri Mulyati, Tasawuf Nusantara; Rangkaian Mutiara Sufi Terkemuka. (Jakarta: Prenada Media Group, 2006). p. 73-77. 
The full name of Shams ad-Din as-Sumatrani is Shams ad-Din 'Abd Allah as-Sumatrani. He is also known as Syams ad-Din Pasai, a great Acehnese scholar who lived in the late 16th and early 17th centuries. It is not known exactly what date and year he was born, but al-Attas noted that the year of his death was $1040 \mathrm{H}$ / $1630 \mathrm{AD}$ The significance and influence of Syams ad-Din is undoubtedly in the sultanate, estimated in the time of the Sultanate of Iskandar Muda. However, he also experienced difficult times during the sultanate of Iskandar Tsani, where ArRaniri and As Sinkili succeeded in bringing Sultan Iskandar Tsani to suppress the teachings of the wahdatul wujud of Ibn 'Arabi firmly held by Syams ad-Din and followers of Hamzah Fansuri for heresy and misleading reasons.

Ar-Raniri's propaganda led to the destruction of his books and legal sanctions for his followers and the prohibition of the Acehnese people to embrace his teachings. Nevertheless, Syams ad-Din was recognized as having a major contribution to the development of Islam at that time. Not a few books of his work and the content of his thoughts in it makes him the best thinker of the time compared to Ar-Raniri. Among the works are: Jauhar Haqâiq (Arabic), Risālat at Tubâyyîn Mulahazhat al Muwahhidîn 'ala Mulhidîn fî Dzikr Allah, Arabic, Dzikr Dâirah Qawsaini al Adnâ (Malay), Mir'ât al Qulûb, Syarh Mir'ât al Qulûb, Kitâb Tazyim, Shi'r al 'Âînnn, Kitâb Ushûl at Tahqîq, Mir'ât al Haqîqat, Kitâb al Martabat, Risâlat al Wahhab, Mir'ât al Muhaqqiqah, Syarh Rubâ'i Hamzah Fansuri (Malay), Taubih Allah, Mir'ât al Mu'minîn (Malay), Syarh Sya'ir Ikan Tongkol (Malay), Nûr ad Daqâiq Malay) and Tharîq as Sâlikîn (Malay). ${ }^{40}$

Al-Raniri has the full name of Nur al-Din Muhammad bin 'Ali bin Hasanji al-Hamid / al-Humayd al-Syafi'i al' Aydarusi al-Raniri was born in an old port city on the coast of Gujarat, namely Ranir. Although he was born in Ranir, Ar-Raniri is more called as a Malay-Indonesian scholar than Indian or Arab. ${ }^{41}$ Because he was a scholar who brought reforms in Malay-Indonesia in the 17th century besides his mother was a Malays while his father came from the family of Hadrami immigrants.

The tracking of the lineage of his father first stems from the family of al Hamid of Zuhra, which is one of the ten families of Quraysh. It is 'Abd al Rahman

${ }^{40}$ M. Ishom Al Saha and Syaeful Hadi, Syekh Syams Ad Din As Sumatrani, on Mastuki HS and M. Ishom El Saha (ed), Intelektualisme Pesantren; Potret Tokoh dan Cakrawala Pemikiran di Era Pertumbuhan Pesantren. (Jakarta: Diva Pustaka, 2003). p. 80-82.

41 Abdollah Vakily, Sufism, Power Politics, and Reform; Al Raniri's Opposition to Hamzah al Fansuri's Teaching Reconsidered. on Studia Islamika, vol. 4, no. 1, 1997. p. 119-120. 
bin' Awf as a member of the well-known Zuhra family as well as the Prophet's companions. Secondly, it is alleged that al-Raniri of the Humayd family, often associated with 'Abu Bakr' Abdullah bin Zubayr al-Asadi al-Humayd (d.29/834), the prominent Makkah ulama who was a prominent and famous student of Imam Asy-Syafi'i. ${ }^{42}$

Regarding the works of ar-Raniri, many talks about Sufism, Jurisprudence, Hadith and Comparative Religion. Among his works are Bustân as Salâthîn fi Dzikr al-Awwalîn wa al-Âkhirîn, Jawâhir al 'Ulûm fî Kasyf al-Ma'lûm, Fath alMubîn, Asy-Syirâth al-Mustaqîm, Hidâyat al Habîb fi at-Targhîb wa at-Tarhîb, Tibyân fi Ma'rifah al-Adyân. ${ }^{43}$

Abu al Ra'uf bin 'Ali al-Jawi al Fansuri as Sinkili is a Malayan cleric from the coastal area of North-West Aceh precisely Fansur. He was born around 1024/1615. al Sinkili's ancestors came from Persia who came to the Sultanate of Pasai Ocean at the end of the 13th century which eventually settled in Fansur. Al Sinkili's father was the brother of Hamzah al Fansuri. However, Azra doubted that opinion and argued that he had some kind of family relationship with him. There is the opinion that al Sinkili's father was an Arab who had married a local woman from Fansur. Although there is no data to support such an opinion, it can be justified as the Pasai and Fansur Oceans are fertile ground for Arab, Persian, Indian, Chinese and Jewish traders from the 9 th century. ${ }^{44}$

At least, there are 22 as-Sinkili works on the subject of fiqh, tafsir, kalam and tasawuf. In writing his work he uses Arabic and Malay. Arabic, however, was the dominant language in writing his works because of his fairly long departure to Arabia, so he realized that the Malay language was not so good. So he was assisted by two Malay language teachers in writing his Malay language. ${ }^{45}$ Among his works are Mir'ât al Thullab fi Tasyil Ma'rifah al Ahkâm al Syar'iyyah li al Mâlik al Wahhab (Malay), Bayân al Arkân (Malay), Bidâyah al Balîghah (Malay), Majmu 'al

42 Azyumardi Azra, Jaringan Ulama Timur Tengah dan Kepulauan Nusantara Abad XVII dan XVIII; Akar Pembaruan Islam. (Jakarta: Kencana, 2004). p. 202.

${ }^{43}$ Azyumardi Azra, Jaringan Ulama Timur Tengah dan Kepulauan Nusantara Abad XVII dan XVIII; Akar Pembaruan Islam. (Jakarta: Kencana, 2004). p. 216-228. See Abdollah Vakily, Sufism, Power Politics, and Reform; Al Raniri's Opposition to Hamzah al Fansuri's Teaching Reconsidered. onStudia Islamika, vol. 4, no. 1, 1997. p. 121-123.

${ }_{44}$ Azyumardi Azra, Jaringan Ulama Timur Tengah dan Kepulauan Nusantara Abad XVII dan XVIII; Akar Pembaruan Islam. (Jakarta: Kencana, 2004). p. 229-232.

45 Azyumardi Azra, Jaringan Ulama Timur Tengah dan Kepulauan Nusantara Abad XVII dan XVIII; Akar Pembaruan Islam. (Jakarta: Kencana, 2004). p. 244. 
Masâ'il (Malay), Fâtihah Syekh Abd ar Rauf (Malay), Tanbîh al 'Âmil fî Tahqîq Kalâm an Nawâfil (Malay), A Description of the Intent of Prayer (Malay), Washiyyah (Malay), The Prayer It is recommended by Sheikh Abd ar Rauf Kuala Aceh (Malay) and Sakarât al Mawt (Malay) is the works of Abd ar Rauf in the field of fiqh and religion. His works in the field of Sufism include Tanbîh al Mâsyi al Mansûb ilâ Tharîq al Qusyasyî (Arabic), 'Umdah al Muhtajîn ilâ Sulûk Maslak al Mufridîn (Malay), Sullam al Mustafidîn (Malay), The Charter on Zikir ( Malay), Kifayah al Muhtâjîn ilâ Masyrab al Muwahhidin al Qâilîn bi Wahdah al Wujûd (Malay), Bayân Aghmad al Masâ'il wa ash Shifât al Wâjibah li Rabb al Ardh wa as Samâwât (Malay), Bayân Tajallî (Malay ), Daqâ'iq al Hurûf (Malay), Risâlah Adab Murîd for Sheikh (Malay), Munyah al I'tiqâd (Malay), Bayân al Itlâq (Malay), Risâlah A'yân Tsâbitah (Malay) Risâlah Ma'rifatullah Road (Malay), Risâlah Mukhtasharah fi Bayân Syurûth asy Syaikh wa al Murîd (Arabic and Malay), The Faith in the Kaifiyah Saying Zikir Lâ Ilâha illa Allah (Malay), Syair Ma'rifah (language Malay), Otak Ilmu Ta sawuf (Malay), 'Umdah al Ansâb (Malay), Idah al Bayân fi Tahqîq Masâ'il al Adyân (Malay), Ta'yîd al Bayân Hasyiyah Idah al Bayân (Malay), Lubb al Kashf wa al Bayân li mâ Yarâhu al Muhtadhar bi al Iyân (Malay), Risâlah Save (Malay), and Syaththariyah (Malay). As for the field of commentary is the Book of Tarjuman al Mustafîd which is the first book of interpretation in the archipelago and in the Islamic world in Malay. While in the field of hadith is Syarh Latîf Arbaîn Hadîtsan li al Imam an Nawawî and Al Mawâ'izh al Badîah who both speak Malay. ${ }^{46}$

Muhammad Yusuf bin 'Abd Allah' Abu al Mahasin at Taj al-Khalwati alMaqassari is the full name of Muhammad Yusuf al Maqassari who was born in $1036 \mathrm{H}$ or $1627 \mathrm{AD} .{ }^{47} \mathrm{Al}$ Maqassari may be the only Malay-Indonesian scholar who made a unique journey in studying and preaching Islam. Travel search science he traveled from his birthplace in Gowa to Cikoang then to Banten and then to Ranir and culminate in the Middle East, precisely in Haramayn and Damascus. The twists and turns of Islam are also rich in wandering, from Sulawesi to Banten and to Sri Lanka and ending in South Africa.

In addition, Muhammad Yusuf al Maqassari was one of the most prominent Malay-Indonesian scholars in the field of science in addition to struggling with physical warfare against the Dutch, leading him to arrest and exile. Among his

${ }^{46}$ Sri Mulyati, Tasawuf Nusantara; Rangkaian Mutiara Sufi Terkemuka. (Jakarta: Prenada Media Group, 2006). p. 103-105. See Azyumardi Azra, Jaringan Ulama Timur Tengah dan Kepulauan Nusantara Abad XVII dan XVIII; Akar Pembaruan Islam. (Jakarta: Kencana, 2004). p. 244-254.

${ }^{47}$ Tudjimah, Syekh Yusuf Makasar; Riwayat dan Ajarannya. (Jakarta: UI Press, 2005). p. 4. 
works are: An Nafhat as Saylaniyyah, ${ }^{48}$ Mathâlib as Sâlikîn, Taj al Asrâr, Kayfiyât al Mughni, Qurrat al 'Ain, Al Fawâ'idh al Yusufiyyah, Sura, Zubdât al Asrâr, Sirr al Asrâr, Al Barakât as Saylaniyyah, Tuhfah al Abrâr li Ahl al Asrâr, Fath Kayfiyyat adz Dzikr, Muqaddimat al Fawâid Allati mâ Lâ Budda min al Aqấ'id, Daf al Balâ', Tahsil al Inâyah wa al Bidâyah, Risâlah Ghâyat al Ikhtisār wa Nihâyat al Intizâr, al Wasiyyât al Mufiyat 'an Maddarat al Hijâb, Hädzihi Fawâid Lazimah Zikr Lâ Ilâha Illa Allah, Tuhfat al Amr fì Fadhlat adz Dzikr, ${ }^{49}$ Hasyiyah, Habl al Warîd li Sa'âdat al Murîd, Kaifiyyat an Nafy wa al Itsbât bi al Hadith al Qudsî, Surat Shaykh Yusuf To Sultan Wazir Goa Karaeng Karungrung Abd Allah, Tuhfat ath Thâlib al Mubtadi wa Minhat as Sâlik al Muhtadi, Safinat an Najâh, and Bidâyat al Mubtadi'. ${ }^{50}$

Al-Palimbani with the full name of 'Abd ash Shamad al Palimbani bin Shaykh' Abd al-Jalil bin Shaykh 'Abd al Wahhab al Mahdani was born in Palembang around $1116 \mathrm{H} / 1704 \mathrm{AD}$ Al Palimbani is a descendant of sayyid from Yemen, precisely Sana'a, who had settled in Kedah in the 17th century then his father was appointed to qadhi in Kedah and traveled to Palembang and then married a local woman then 'Abd ash Shamad was born in this area which then not for some time he was taken to Kedah by his parents. In Kedah and Pattani al Palimbani then get an education that greatly affects the intellectual journey in the future. Al Palimbani is also known as a hunter of science, he was never satisfied with the science that he had so far. So he travels studying to Haramain on the advice of his father. In Haramain he is also a lot of friends with many students from the archipelago, some of them are Muhammad Arsyad Al Banjari, 'Abd Wahhab Bugis,' Abd Rahman al Batawi and Daud al Fatani. With the friendship of fellow students of the archipelago make him sensitive to the socio-religious and political situation in these islands. ${ }^{51}$

His extensive association and persistence with many scholars in Haramain both locally or Morocco, Egypt and Zabid made him a Palembang scholar who has a network of scholars is very broad and productive in producing papers. Among his scientific works include: Zuhrah al Murîd fî̀ Bayân Kalimah at Tauhîd (1764),

${ }_{48} \mathrm{P}$. Voorhoeve, Handlist of Arabic Manuscript in the Library of the University of Leiden and Other Collections in the Netherlands. (Leiden: 1957). p. 539.

${ }^{49}$ Tudjimah, Syekh Yusuf Makasar; Riwayat dan Ajarannya. (Jakarta: UI Press, 2005). p. 21.

${ }^{50}$ Affandi Muchtar and Maksum, Syekh Yusuf al Maqassari, on Mastuki HS dan M. Ishom El Saha (ed), Intelektualisme Pesantren; Potret Tokoh dan Cakrawala Pemikiran di Era Pertumbuhan Pesantren. (Jakarta: Diva Pustaka, 2003). p. 160-165.

${ }^{51}$ Khoiron Sirin and Moch. Khoiron, Syekh 'Abd al Shamad al Palimbani, on Mastuki HS dan M. Ishom El Saha (ed), Intelektualisme Pesantren; Potret Tokoh dan Cakrawala Pemikiran di Era Pertumbuhan Pesantren. (Jakarta: Diva Pustaka, 2003). p. 139-142. 
Nashîhah al-Muslimîn wa Tadzkirah al Mu'minîn fî Fadhấil al Jihād fi Sabîlillah wa Karîmah al Mujâhidin fí Sabîlillah (1772), Tuhfah ar Rāghibîn fì Bayân Haqîgah Îmân al Mu'minin wa Mâ Yufsiduh fî̀ Riddah al Murtaddîn (1774), Al 'Urwah al Wutsqâ wa wa sshi Shaad, Zâd al Muttaqîn fì Tauhîd Rabb al'Alamin, Hidâyah as Sâlikîn fì Sulûk Maslak al Muttaqîn (1787), ${ }^{22}$ Sayr as Sâlikîn ilâ Rabb al 'Âlamîn.53

Muhammad Arsyad al Banjari was born in the village of Lok Gabang, Martapura, South Kalimantan on 15 Shafar 1122 H / 19 March 1710 AD His father was named 'Abd Allah and his mother named Siti Aminah and he grew up in a religious environment. At the age of seven, he was asked by his parents to be adopted by Sultan Tahlil Allah (1700-1745) after the sultan learned of his intelligence. For 23 years al Banjari lives in the Sultanate of Banjar, this is where al Banjari get a better education from teachers who brought in by the Sultan. Exactly 30 years old, at the cost of the palace, al Banjari went to continue the odyssey of science in Haramain, 30 years he spent in Makkah and 5 years he spent in Medina. In the month of Ramadan 1186 H / December $1772 \mathrm{AD}$, he returned to Banjar to practice his knowledge.

The long time in the hunt for science in Haramain confirms the maturity of al Banjari in all fields of science, both fardhu 'ain and fardhu kifayah, such as geography, biology, mathematics, geometry, and astronomy. Therefore, Imam Haramain suggested al-Banjari and his three friends, namely 'Abd al-Shamad alPalimbani,' Abd al-Wahab Bugis and 'Abd ar-Rahman al-Mashri al-Batawi, to return to their homes without having to study again to Egypt.

Al-Banjari is known as an astronomer, educational expert, "engineer" of agriculture, $m u f t \hat{\imath},{ }^{4} f a q i \hat{h}$ and also a Sufi. His expertise in astronomy proved with his thoroughness showing the right direction in the mosques of Jakarta, Palembang, and Banjarmasin. His expertise in the field of education is seen with the establishment of educational institutions model of pesantren in Java and Surau in Minangkabau and his engineering can be deduced from the shrewd use of land around paddy fields and vegetable gardens. His writings also include the fiqh, aqidah and tasawuf fields, among others: Sabîl al Muhtadîn, Luqthah al Ajlan, Kitâb

\footnotetext{
${ }^{52}$ See 'Abd ash-Shamad al-Palimbani, Hidayah as Salikin. (Indonesia: Syirkah Maktabah al Madaniyyah, $1351 \mathrm{H}$ ).

${ }^{53}$ Khoiron Sirin and Moch. Khoiron, Syekh 'Abd al Shamad al Palimbani, on Mastuki HS and M. Ishom El Saha (ed), Intelektualisme Pesantren; Potret Tokoh dan Cakrawala Pemikiran di Era Pertumbuhan Pesantren. (Jakarta: Diva Pustaka, 2003). p. 142-144.

${ }_{54}$ Azyumardi Azra, Jaringan Ulama Timur Tengah dan Kepulauan Nusantara Abad XVII dan XVIII; Akar Pembaruan Islam. (Jakarta: Kencana, 2004). p. 319.
} 
an Nikâh, Kitâb al Farâidl, Ushûl ad Dîn, Tuhfah ar Râghibîn fi Bayân Haqîqah Imâm alMu'minîn wa Ma Yufsiduh min Riddah al Murtaddîn, Qaul al Mukhtashar fí 'Alamah alMahd al Muntazhar, Tarjamah Fath ar Rahmân and Kanz al Ma'rifah..$^{55}$

The full name of al Fattani according to Wan Mohd. Shaghir Abdullah is Wan Dawud bin Wan Abdullah bin Wan Idris bin Wan Abu Bakr bin Wan Ismail bin Andi Faqih Ali Datok Maharajalela. ${ }^{56}$ Referring to the work of al Fattani, he introduced himself by the name of Shaykh Dawud bin 'Abd Allah bin Idris al-Jawi al-Fattani al-Malayuwi who is also known by the name of Shaykh Dawud bin Abdullah bin Senik Fattani. As for the birthplace, he was a different opinion. There are at least three places of his debated birth, first, in the area of Kerisek which is believed by most residents of Kerisek and his pupil, Tok Kelaba; secondly, in the Parit Marhum area close to Kerisek as reported by Sheikh Muhammad Nur bin Muhammad bin Ismail al Fattani in the Book of Kifâyât al Mubtadi, commentary on Sullam al Mubtadî by Sheikh Dawud al Fatani; third, his last opinion was born in the Gucir Bend area adjacent to Kerisek, but this opinion is not proved by solid evidence. ${ }^{57}$

From the opinions above, it can be concluded that al Fatani was born in Kerisek or in Parit Marhum. Although both are different both are included in the territory of Patani, an area that was under the Sultanate of Malaysia in the past. The year of his birth was in $1153 \mathrm{H}$, coinciding with 1769 AD. ${ }^{58}$

Sheikh Dawud al Fattani is the most prolific scholar of the archipelago spawning scientific papers. No less than 60 of his works are documented in Malaysia, both in the State Library of Malaysia and in the Malaysian Islamic Museum. ${ }^{59} \mathrm{Al}$ Fatani's works include: 'Aqidat al Jawâhir, Bâb an Nikâh, Bâb al Jinâyah, Al Bahjât al Mardhiyyah, Al Bahjât al Saniyyah fì al' Aqa'id as Saniyyah, Al Bahjat al Wardiyyah, Bayān al Ahkâm, Bidâyat al Hidayah, Bisharat al Ikhwân bi Asbâb al Mawt

${ }^{55}$ Zaenul Mahmudi and Imam Safe'i, Syekh Muhammad Arsyad al Banjari, on Mastuki HS and M. Ishom El Saha (ed), Intelektualisme Pesantren; Potret Tokoh dan Cakrawala Pemikiran di Era Pertumbuhan Pesantren. (Jakarta: Diva Pustaka, 2003). p. 112.

${ }^{56}$ Wan Mohd. Shaghir Abdullah, Syeikh Daud bin Abdullah al Fatani; Ulama dan Pengarang Terulung Asia Tenggara. (Shah Alam: Penerbit Hizbi, 1990). p. 9.

${ }^{57}$ Mohd. Zain Abd Rahman, New Lights on the Life and Works of Shaikh Dawud al Fattani, on Studia Islamika, Vol. .9, No. 3, 2002. p. 88-89.

58 Azyumardi Azra, Jaringan Ulama Timur Tengah dan Kepulauan Nusantara Abad XVII dan XVIII; Akar Pembaruan Islam. (Jakarta: Kencana, 2004). p. 327.

${ }_{59}$ Mohd. Zain Abd Rahman, New Lights on the Life and Works of Shaikh Dawud al Fattani, on Studia Islamika, Vol. .9, No. 3, 2002. p. 93-94 
'alâ al Îman, Bughyat ath Thullab li al Murîd Ma'rifah al Ahkâm bi ash Shawâb, Bulûgh al Marâm fì Kayfiyyah Muqâranât Takbîrat al Ihrâm, Diya' al Murî̀ fî̀ Ma'rifah Kalimah at Tawhîd, Ad Durr ath Thamim fì 'Aqấ'id al Mu'minîn, Fath al Mannan lî Shafwah az Zubad, Fatwa Selling with Infidels, Farâ'id al Fikri fi al Imam al Mahdi, Furû' al Masâ'il wa Ushîl al Masâ'il, Ghayah al Marâm fì Kayfiyyah there is' al Hajj (fî) al Islâm I Manâsik al Hajj wa al 'Umrah, Ghâyah at Taqrib fi Irts wa at Ta'shîb, Hidâyah al Muta'allimîn wa' Umdah al Mu'allim, Hikayat Men Salih than Ban̂̀ Isrầll, Hayd's Law and Istihâdhah, Idhah al Bâb al Murîd an Nik ash Shawâb, 'Iqd al Jawâhir, Jam' al Fawầ'id, Al Jawâhir as Saniyyah, Jihâyah at Takhtub, Kanz al Minan 'alâ Hikam Ab̂̀ Madyan, Kashf al Ghummah fî Ahwâl al Mawtâ fî al Barzakh wa al Qiyâmah, Kayfiyyah Khatam al Qur'an, Kayfiyyah al Mubtadi, Kayfiyyah Shalât Tarâwîh, Kifayah al Muhtaj fi al Isrâ 'wa al Mi'râj, Al Manhal ash Shâfî fi Bayân Ramz Ahl ash Shûfi, Minhâj al' âbidîn, Mudzâkarah, Munyah al Mushallî, Musawwaddah Muta'allim, Nahj ar Râghibin wa Sabîl al Muhtadîn, Nubdhah fì Bayân Shurût al Jum'ah, Qismah az Zakâh bayn al ashnâf, Qishshah Prophet Yûsuf, Al Qurbah ilâ Allah, Risâlah Answer Questions, Risâlah Excess Basmalah, Risâlah Excess Hamdalah, Risâlah Ta'alluq bi kalimah al Îmân, Risâlah ath Tharîah asy Syattariyyah wa as Sammaniyyah, Risâlah al Masấil, As Sayd wa adz Dzaba'ib, Sullam al Mubtadi fî̀ Bayân Tharîqat al Muhtadî, Ta'lîq Latîf mimmâ Yata'allaq bi Jawâz Ta'addud al Ju m'ah, Tanbîh al Ghâfilîn, Târikh Patani, Tuhfah al Ikhwân fî Nishf Sya'bân, Tuhfah ar Râghibîn fî̀ Sulûk Tharîq al Muttaqîn, Tuhfah ar Râghibîn fî̀ Bayân Haqîaah Îmân al Mu'minîn, Ward az Zawâhir li Hâll Alfâz 'Iqd al Jawâhir and Washâyâ al Abrâr wa Mawâ'iz al Akhyâr. ${ }^{60}$

Departing from the above discussion, it can be concluded that Malay Arabs play a very important role in Islamic literacy tradition in the archipelago and the formation of its people. It is the first letter of the archipelago that is widespread and popular where the achievement has not been achieved by the previous or subsequent script. Although the title of the work of the archipelago of the archipelago using the Arabic language but the contents remains dominated by the Malay language. Thus, Malay is the second largest language after Arabic in the study of Islamic sciences and broadcasting.

\section{Conclusion}

Arabic has an important role in shaping literacy in Indonesia. Arabic influences on Indonesian (read: Malay) from script to semantic, lexicographic, and grammatical. So that the Indonesian language becomes a tool of hegemonic

${ }^{60}$ Mohd. Zain Abd Rahman, New Lights on the Life and Works of Shaikh Dawud al Fattani, on Studia Islamika, Vol. .9, No. 3, 2002. p. 94-104. 
domination and power as well as the key to peace in the archipelago of Malay Archipelago.

Thousands of manuscripts were born from the hands of Muslim clerics where this has never happened in the archipelago of Malay Archipelago except after contact with Islam which is very synonymous with Arabic. Hamzah Fansuri, Shams ad-Din as-Sumatrani, Ar-Raniri, As-Sinkili, Muhammad Yusuf alMaqassari, Nawawi al-Bantani, Al-Palimbani, Arsyad al-Banjari and Dawud alFattani were considered as the lucrative tradition traders in the archipelago it has simultaneously introduced universality and rationality to the inhabitants of this archipelago.

\section{Bibliography}

Abdullah, Wan Mohd. Shaghir. 1990. Syeikh Daud bin Abdullah al Fatani; Ulama dan Pengarang Terulung Asia Tenggara. Shah Alam: Penerbit Hizbi.

Acikgenc, Alparslan. 1996. Islamic Science; towards a Definition. Kuala Lumpur: ISTAC.

Al-Attas, Syed Naquib. 1969. Preliminary Statement on a General Theory of the Islamization of the Malay-Indonesian Archipelago. Kuala Lumpur: Dewan Bahasa dan Pustaka.

Al-Attas,Syed Muhammad Naquib. 1984. Islam Dalam Sejarah Dan Kebudayaan Melayu. Bandung: Mizan.

Al Attas, Syed Naquib. 1993. Islam and Secularism. Kuala Lumpur: ISTAC.

Al-Palimbani, 'Abd ash-Shamad. 1351 H. Hidayah as Salikin. Indonesia: Syirkah Maktabah al Madaniyyah.

AR, D. Sirodjuddin. 1985. Seni Kaligrafi Islam. Jakarta: Pustaka Panjimas.

AR, D. Sirojuddin. 1994. Potret dan Pengembangan Seni Kaligrafi Islam di Indonesia, on LPTQ Tingkat Nasional, 25 Tahun Musabaqah Tilawatil Qur'an. Jakarta: LPTQ.

Arnold, T.W. 2002. The Preaching of Islam; A History of Propagation of the Muslim Faith. New Delhi: Aryan Books International.

Azra, Azyumardi. 1999. Pendidikan Islam; Tradisi dan Modernitas Menuju Milenium Baru. Ciputat: Logos.

Azra, Azyumardi. 1999. Esei-esei Intelektual Muslim dan Pendidikan Islam. Ciputat: Logos. 
Azra, Azyumardi. 2004. Jaringan Ulama Timur Tengah dan Kepulauan Nusantara Abad XVII dan XVIII; Akar Pembaruan Islam. Jakarta: Kencana.

Azra, Azyumardi. 2006. Renaisans Islam Asia Tenggara; Sejarah Wacana dan Kekuasaan. Bandung: PT Remaja Rosdakarya.

Bakker, Anton and Achmad Charris Zubair. 1998. Metodologi Penelitian Filsafat. Yogyakarta: Kanisius.

Baudrillard, Jean. 1981. For a Critique of the Political Economy of the Sign, translated by C. Levin. St. Louis: Telos Press.

Beerling, R.F. S.L. Kwee, J.J.A. Mooij and C.A van Peursen. 1986. Pengantar Filsafat Ilmu. Yogyakarta: Tiara Wacana.

Braginsky, Vladimir. 2004. The Herritage of Tradinional Malay Literature; A Historical Survey of Genres, Writings and Literary Views. Leiden: KILTV Press.

Fairchild, Henry Pratt (ed). Dictionary of Sosiology and Related Sciences. New York: Littlefield, Adam \& Co. Ottowa.

Franca, Antonio Pinto da. 2000. Pengaruh Potugis di Indonesia, translated by Katoppo. Jakarta: PT. Penebar Swadaya.

Hollander, J.J. de. 1984. Pedoman Bahasa dan Sastra Melayu. Jakarta: Balai Pustaka.

HS, Mastuki and M. Ishom El Saha (ed). 2003. Intelektualisme Pesantren; Potret Tokoh dan Cakrawala Pemikiran di Era Pertumbuhan Pesantren. Jakarta: Diva Pustaka.

Jones, Russell (ed). 2008. Loan-Words in Indonesia and Malay. Jakarta: KITLV dan Yayasan Obor Indonesia.

Lubis, Nabilah. 1998. Pentingnya Pendekatan Filologi dalam Studi Keislaman. Jakarta: IAIN Syarif Hidayatullah.

Madjid, Nurcholish. 2004. Indonesia Kita. Jakarta: Universitas Paramadina.

Meuleman, Johan (ed). 2001. Islam in The Era of Globalization: Muslim Attitudes Towards Modernity and Identity. Jakarta: INIS.

Muhammad, Mat Akhir Haji Sanawi. 1403/1983. Kitabah al Lughah al Malaziyah bi al Huruf al 'Arabiyyah. Khurthum: Risalah Diplom Ma'had Khurthum ad Dauly.

Mulyati, Sri. 2006. Tasawuf Nusantara; Rangkaian Mutiara Sufi Terkemuka. Jakarta: Prenada Media Group. 
Mu'jizah. 2009. Iluminasi dalam Surat-surat Melayu Abd ke-18 dan ke-19. Jakarta: KITLV dan Pusat Bahasa-Depatemen Pendidikan Nasional.

Praja, Juhaya S. Filsafat dan Metodologi Ilmu dalam Islam dan Penerapannya di Indonesia. Bandung: Teraju, 2002.

Ricoeur, Paul. 1982. Hermeunetics and the Human Sciences; Essays on Language, Action and Interpretation. Cambridge: Cambridge University Press.

Schimmel, Annemarie. 1995. Islamic Names. Edinburgh: Edinburgh University Press.

Shafiqullah, Shah Muhammad. 1993. Calligraphic Ornamentation in The Architecture of The Umayyad of Syria: A Brief Survey, dalam The Islamic Quarterly: A Review of Islamic Culture. London: Volume XXXVII.

Teeuw,A. 1994. Indonesia Antara Kelisanan dan Keberaksaraan. Jakarta: Pustaka Jaya.

Tehranian, Majid. 1990. Technologies of Power: Information Machines and Democratic Prospects. New York: Ablex Publishing Company.

Tjadrasasmita, Uka. 2006. Kajian Naskah-Naskah Klasik dan Penerapannya bagi Kajian Sejarah Islam di Indonesia. Jakarta: Puslitbang Lektur Keagamaan Depag.

Tjandrasasmita, Uka. 2006. An Explanation of the Study of Philology and its Application to the Study of Islamic History in Indonesia. on Jurnal Lektur Keagamaan, vol. 4 , No. 1.

Tudjimah. 2005.Syekh Yusuf Makasar; Riwayat dan Ajarannya. Jakarta: UI Press.

Voorhoeve, P. 1957. Handlist of Arabic Manuscript in the Library of the University of Leiden and Other Collections in the Netherlands. Leiden: University of Leiden.

Wijk, D. Gerth van. 1985. Tata Bahasa Melayu. Jakarta: Djambatan.

Yeob, Shamsul Jamili. 1996. The Influence Arabic Language on Modern Malay Arabic Metaphor in Malay Words. Leeds: Thesis in Arabic Studies at University of Leeds.

Al-Turats, vol. 7, no. 11, Januari 2001.

Ensiklopedi Tematis Dunia Islam. Jakarta: Ichtiar Baru van Hopeve, 2002.

Studia Islamika, vol. 4, no. 1, 1997.

Studia Islamika, Vol. .9, No. 3, 2002. 